\title{
Identification of an Antifungal Chitinase from a Potential Biocontrol Agent, Bacillus cereus 28-9
}

\author{
Chien-Jui Huang, Tang-Kai Wang, Shu-Chun Chung and Chao-Ying Chen* \\ Department of Plant Pathology and Microbiology, National Taiwan University, Taipei, Taiwan, Republic of China
}

Received 7 August 2004, Accepted 22 September 2004

\begin{abstract}
Bacillus cereus $28-9$ is a chitinolytic bacterium isolated from lily plant in Taiwan. This bacterium exhibited biocontrol potential on Botrytis leaf blight of lily as demonstrated by a detached leaf assay and dual culture assay. At least two chitinases (ChiCW and $\mathrm{ChiCH}$ ) were excreted by $B$. cereus 28-9. The ChiCW-encoding gene was cloned and moderately expressed in Escherichia coli DH5 $\alpha$. Near homogenous ChiCW was obtained from the periplasmic fraction of $E$. coli cells harboring $c h i C W$ by a purification procedure. An in vitro assay showed that the purified ChiCW had inhibitory activity on conidial germination of Botrytis elliptica, a major fungal pathogen of lily leaf blight.
\end{abstract}

Keywords: Antifungal activity, Chitinase, ChiCW, Gene cloning, Protein purification

\section{Introduction}

Chitin is an insoluble linear $\beta$-1,4-linked polymer of $N$ acetylglucosamine (GlcNAc). It is a major constituent of the cell wall of many fungi, insect exoskeletons, and crustacean shells (Bartnicki-Garcia 1969; Sietsma and Wessels, 1979; Gooday 1990; Cohen-Kupiec and Chet 1998). Chitinases (EC 3.2.1.14) are found in a broad range of organisms, including bacteria, fungi, and higher plants, and play different roles in their origin (Flach et al., 1992; Graham and Sticklen, 1994; Felse and Panda, 1999). Chitinase-producing microorganisms have been reported as biocontrol agents for different kinds of fungal diseases of plants (Chernin et al., 1995; Kobayashi et al. 2002; Freeman et al., 2004). However, no chitinolytic microorganism has been reported for use in biocontrol of Botrytis leaf and flower blight of lily which causes severe economic loss of cut-flower production in Taiwan (Hsieh and

\footnotetext{
*To whom correspondence should be addressed.

Tel: +886-2-23657735; Fax: +886-2-23636490

E-mail: cychen@ntu.edu.tw
}

Huang, 1998). Fungicides have been used in high frequency to control this disease, but difficulty in chemical control is increasing due to a rapid development of fungicide resistance by B. elliptica (Chastagner and Riley, 1990; Migheli et al., 1990). Therefore, biological control involving two or more mechanisms has been chosen as a good alternative for practical use in the control of Botrytis blight (Elad, 1996; Chiou and $\mathrm{Wu}, 2001$ ).

Bacillus cereus is a large, gram-positive, endosporeforming bacterium that is very common in soils and plants (Brunel et al., 1994; Martinez et al., 2002). For plant disease control, B. cereus UW85, which is capable of producing two antibiotics responsible for disease suppression (Silo-Suh et al., 1994), has been proven to be a reliable biocontrol agent of Phytophthora damping off and root rot of soybean (Emmert and Handelsman, 1999). An endophytic B. cereus strain 65 producing a chitobiosidase is also found effective against $R$. solani in cotton (Pleban et al., 1997). However, the role of chitobiosidase in the antagonism of B. cereus strain 65 toward fungal pathogens is not clearly understood.

In this study, a chitinolytic bacterium B. cereus 28-9 from lily plant was investigated on its potential biocontrol activity against $B$. elliptica. A chitinase-encoding gene was cloned from B. cereus 28-9 and expressed in Escherichia coli. This chitinase was purified from a recombinant $E$. coli and used to demonstrate its antifungal activity.

\section{Materials and Methods}

Bacterial strains and culture conditions $\quad$ B. cereus 28-9 isolated from lily plant in Taiwan showed high chitinase activity on the colloidal chitin plate $(1 \times \mathrm{M} 9$ salts, $0.5 \%$ yeast extract, $0.2 \%$ colloidal chitin, and $1.5 \%$ agar). E .coli DH5 $\alpha$ (Bethesda Research Laboratories, USA) was used as a host to express foreign chitinase. Bacteria were cultured in Luria-Bertani (LB) medium supplemented with ampicillin at a final concentration of $50 \mu \mathrm{g} / \mathrm{ml}$ if necessary.

Antagonistic activity assay Dual culture assay and leaf disc assay were performed to assess the potential biocontrol activity of 
B. cereus 28-9. B. elliptica B061, as a target fungus, was cultured on V-8 agar slant [20\% V-8 juice (Campbell Soup Co., Camden, USA), $0.3 \% \mathrm{CaCO}_{3}, 1.8 \%$ agar] at $20^{\circ} \mathrm{C}$ under near-UV light to induce sporulation (Doss et al., 1984). In the dual culture assay, conidial suspension of $B$. elliptica B061 and bacterial suspension of B. cereus 28-9 were streaked on the surface of LB agar at a distance of $4 \mathrm{~cm}$. The growth of both was examined daily for the formation of inhibition zone. In the detached leaf assay, the bulbs of oriental lily cv. Star Gazer (Lilium oriental hybrid) were grown for four weeks to provide leaf discs. Leaf discs (15 mm diameter) were cut from the middle leaves and placed on water-soaked filter paper in Pyrex petri dish. Bacterial suspension of B. cereus 28-9 was atomized on the abaxial surface of lily leaves before, simultaneously with, or after the atomization of conidial suspension of $B$. elliptica B061 $\left(5 \times 10^{4}\right.$ conidia/ml, prepared in sterile distilled water containing $0.05 \%$ Tween 20 ). The disease severity on each leaf disc was recorded as the percentage of necrotic area three days after inoculation. Four leaf discs were used in each treatment. The experiment was repeated three times.

Cloning of chitinase-encoding gene from B. cereus 28-9 A genomic library was constructed in Lambda ZAPII (Stratagene, La Jolla, USA) using EcoRI-digested genomic DNA of B. cereus 28-9. The genomic DNA of B. cereus 28-9 was isolated and purified using a method described by Keim et al. (Keim et al., 1997). EcoRI partially digested genomic DNA of 4 to $8 \mathrm{~kb}$ was size-fractionated by preparative agarose gel electrophoresis and purified from the gel with a Geneclean II kit (Bio-101, La Jolla, USA). The DNA fragments were ligated into EcoRI-digested, phosphatased Lambda ZAPII arms. After in vitro lambda packaging, E. coli XL1-Blue MRF' cells $\left(\mathrm{OD}_{600}=0.5\right)$ were infected with recombinant phages and grown on NZY plates $\left(0.5 \% \mathrm{NaCl}, 0.2 \% \mathrm{MgSO}_{4} \cdot 7 \mathrm{H}_{2} \mathrm{O}, 0.5 \%\right.$ yeast extract, $1 \%$ casein hydrolysate, $1.5 \%$ agar) which were overlayed with LB top agar containing $0.2 \%$ colloidal chitin. E. coli XL1-Blue MRF' cells infected by recombinant phages carrying chitinase genes were screened for the formation of clearer plaque after culturing at $37^{\circ} \mathrm{C}$ for several days. Subsequently, DNA inserts in positive phages were excised in vivo by rescue of a pBlueScript SK phagemid after superinfection with a helper phage. The nucleotide sequence of DNA insert was determined using an autosequencer ABI-310 (Applied Biosystems, Foster City, USA) and analyzed with the software of NCBI (National Center for Biotechnology) or the Genetics Computer Group (GCG) Wisconsin Package.

Southern blot analysis The genomic DNA of B. cereus 28-9 was digested with restriction enzymes. After agarose gel electrophoresis, the DNA fragments were blotted onto a Hybond-N+ nylon membrane (Amersham Biosciences). DNA probe was prepared using a PCR DIG probe synthesis kit (Roche Diagnostics GmbH, Mannheim, Germany), following the method as described by the manufacturer. The nylon membrane was hybridized with the DIGlabeled DNA probe, following by immunodetection with a DIG luminescent detection kit (Roche Diagnostics $\mathrm{GmbH}$ ) and high performance chemiluminescence film (Hyperfilm ${ }^{\mathrm{TM}} \mathrm{ECL}^{\mathrm{TM}}$, Amersham Biosciences).

SDS-PAGE and zymogram analysis Sodium dodecyl sulfate- polyacrylamide gel electrophoresis (SDS-PAGE) was performed according to Laemmli procedure (Laemmli, 1970) using the MiniProtean II apparatus (Bio-Rad, Herculus, USA). A 10\% separating gel containing $0.01 \%$ glycol chitin as the substrate of chitinase was used to detect chitinase activity. After electrophoresis, proteins in the gel were renatured in $0.1 \mathrm{M}$ sodium acetate buffer $(\mathrm{pH} 5.0)$ containing $1 \%$ Triton $\mathrm{X}-100$ at $37^{\circ} \mathrm{C}$. Subsequently, the gel was stained with $0.01 \%$ Calcofluor White M2R (Sigma, St. Louis, USA) in 0.5 M Tris- $\mathrm{HCl}$ ( $\mathrm{pH} 8.9$ ) and examined for the chitinolytic bands under UV transilluminator (Trudel and Asselin, 1989). In another gel, proteins were stained with Coomassie Brilliant Blue G250 .

Chitinase activity measurements A fluorometric assay was used to determine chitinase activity using 4-methylumbelliferylN,N',N"-chitotriose (Sigma, St. Louis, USA) as a substrate. The amount of 4-methylumbelliferone (4-MU) released was measured spectrofluorometrically by using a fluorescence spectrophotometer (F-4500, Hitachi) (excitation $390 \mathrm{~nm}$ and emission $450 \mathrm{~nm}$ ). One unit $(\mathrm{U})$ of chitinase activity was defined as the amount of enzyme required to release one $\mu \mathrm{mol}$ of $4-\mathrm{MU}$ per min at $37^{\circ} \mathrm{C}$. Protein concentration was determined by Bradford's method (Bradford, 1976) using bovine serum albumin as standard.

Expression and purification of chitinase from $E$. coli cells Fulllength chitinase-encoding gene was amplified by polymerase chain reaction with a pair of oligonucleotide primers, cwf 5'-GGAATTC GAAAGGAGAAATGGCATGAGGTC-3' and cwr 5'-GGAATTC CTAGTTTTCGCTAATGAC-3'. The amplified fragment was ligated into pCR2.1-TOPO (Invitrogen, Carlsbad, USA) and transformed into E. coli $\mathrm{DH} 5 \alpha$. Recombinant $E$. coli $\mathrm{DH} 5 \alpha$ harboring chitinase gene was cultured in LB broth supplemented with $50 \mu \mathrm{g} / \mathrm{ml}$ ampicillin on a rotary shaker at $37^{\circ} \mathrm{C}$ for $20 \mathrm{~h}$ and harvested by centrifugation $(8,000 \times g, 10 \mathrm{~min})$. The periplasmic fraction of $E$. coli cells was prepared by an osmotic shock method (Manoil and Beckwith, 1986). The proteins were precipitated by adding solid ammonium sulfate to $70 \%$ saturation. The precipitate was dissolved in $25 \mathrm{mM}$ Tris- $\mathrm{HCl}$ buffer, $\mathrm{pH} 8.5$ and dialyzed overnight against the same buffer. The dialysate was applied to an anion-exchange (Q Ceramic HyperD) column (Sigma, St. Louis, USA) equilibrated with the same buffer. Proteins were eluted with 0.1 to $0.5 \mathrm{M} \mathrm{NaCl}$ gradient in $25 \mathrm{mM}$ Tris- $\mathrm{HCl}$ buffer, $\mathrm{pH}$ 8.5. Active fractions with chitinase activity were pooled and dialyzed against $100 \mathrm{mM}$ potassium phosphate buffer, $\mathrm{pH}$ 6.0. All purification steps were carried out at $4^{\circ} \mathrm{C}$.

Antifungal assay of ChiCW Purified chitinase from E. coli was used for antifungal assay. Conidia of B. elliptica B061 was used as a target and the concentration of conidial suspension was adjusted to $10^{5} \mathrm{conidia} / \mathrm{ml}$. In each treatment, $4 \mu \mathrm{l}$ of enzyme solution was mixed with $4 \mu \mathrm{l}$ of conidial suspension and incubated at room temperature for $12 \mathrm{~h}$. The germination of 100 conidia was examined under a light microscope and the percentage of inhibition was calculated. The experiment was repeated three times.

Nucleotide sequence accession number The nucleotide sequence of chiCW has been deposited in the GenBank database under accession number AF416570. 


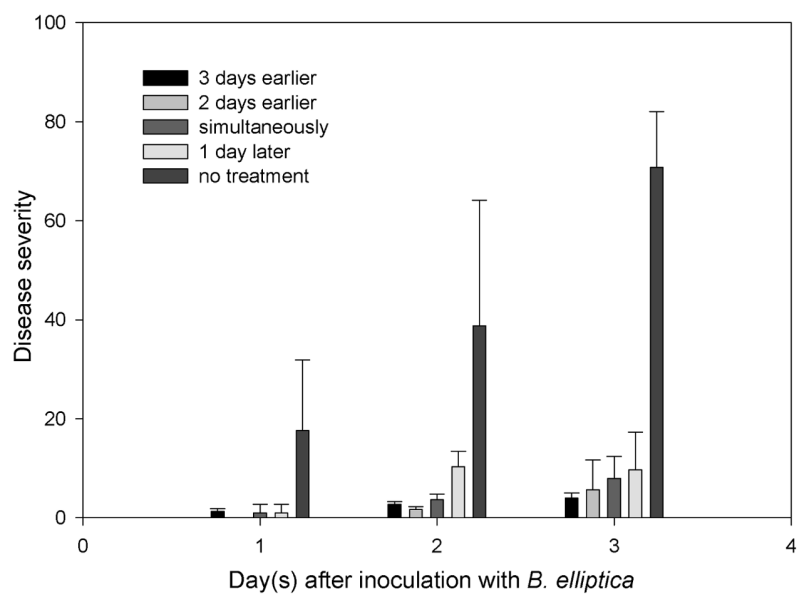

Fig. 1. Biocontrol potential assay on B. cereus 28-9 against $B$. elliptica. B. cereus $28-9$ at a concentration of $2 \times 10^{8} \mathrm{CFU} / \mathrm{ml}$ was sprayed onto lily leaf discs at the following time points: 3 days prior to, 2 days prior to, simultaneously with, or 1 day after inoculation with conidial suspension of B. elliptica B061. The symptom development on the lily leaf discs were observed three days after inoculation with $B$. elliptica.

\section{Results}

Biocontrol potential of $\boldsymbol{B}$. cereus 28-9 The antagonistic activity of $B$. cereus 28-9 against fungi was demonstrated by dual culture assay and a detached leaf assay against $B$. elliptica B061. In the detached leaf assay, when B. cereus 28-9 was applied at a concentration of $2 \times 10^{8} \mathrm{CFU} / \mathrm{ml}$ simultaneously to the leaf disc inoculated with conidial suspension, a significant inhibition on the development of lesions was observed. The necrotic lesions appeared browning in a very few cells without undergoing water soaking. Furthermore, the development of lesions was significantly suppressed when $B$. cereus $28-9$, also $2 \times 10^{8} \mathrm{CFU} / \mathrm{ml}$, was applied two or three days before or one day after inoculation with B. elliptica B061 (Fig. 1). Dual culture of B. cereus 28-9 and B. elliptica B061 showed that $B$. cereus 28-9 inhibited the growth of $B$. elliptica B061 in vitro by secreting antifungal compound(s) out of the bacterial cells, as indicated by the formation of inhibition zone.

ChiCW-encoding gene The chitinase-encoding gene was cloned by functional expression of Bacillus chitinase in $E$. coli. Four clones that exhibited chitinolytic activities were selected. A phagemid with a $4.5-\mathrm{kb}$ insert was rescued from the recombinant phage by in vivo excision. Nucleotide sequencing analysis revealed an open reading frame (ORF) consisting of 2,022 nucleotides with ATG as a start codon and TAG as a stop codon. This ORF encoded a protein (named as ChiCW precursor) of 674 amino acid residues with a calculated molecular weight of 74.261 and a putative pI of 5.77. The putative Shine-Dalgarno sequence, AGGAGA, was located seven nucleotides upstream of the start codon. The -35 region (TTTACA) and -10 region (TTTAAT) of a putative

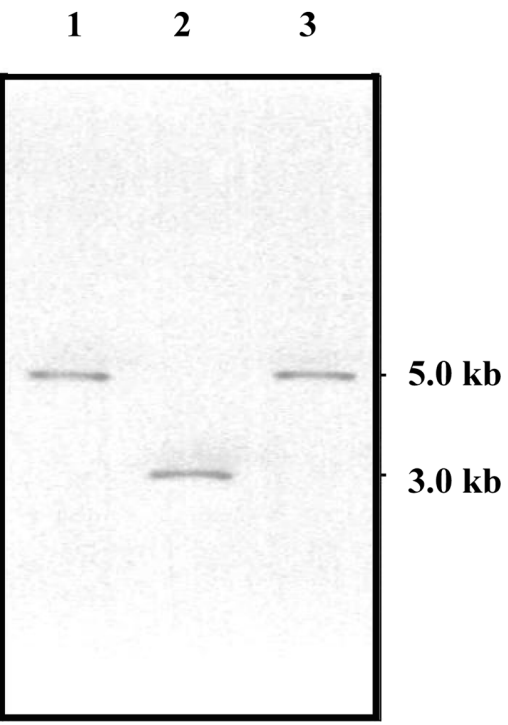

Fig. 2. Southern blot analysis of the genomic DNA of B. cereus 28-9. The genomic DNA was digested with EcoRI (lane 1), EcoRV (lane 2) or HindIII (lane 3). The DNA probe was generated to target chiCW gene.

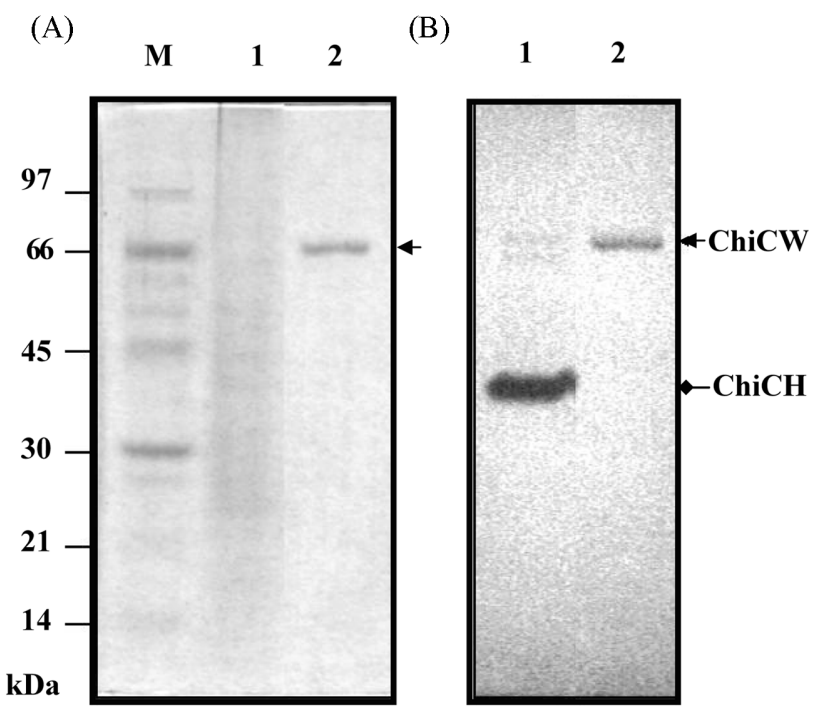

Fig. 3. SDS-PAGE and in-gel activity assay. Proteins from the culture supernatant of B. cereus 28-9 (lane 1) and ChiCW purified from the periplasmic fraction of E. coli DH5 $\alpha$ (pNTU55) (lane 2) were analyzed by SDS-PAGE in a $10 \%$ polyacrylamide gel containing $0.01 \%$ glycol chitin. One gel was stained with Coomassie Brilliant Blue (A) and another gel was stained with Calcofluor White M2R (B). ChiCW is indicated by the arrow (ca. $70 \mathrm{kDa}$ ). M, low molecular weight protein standards (Amersham Biosciences).

promoter sequence were found upstream of chicW by computer analysis. Southern blot analysis showed single band signal in EcoRI-, EcoRV- and HindIII-digested genomic DNA of $B$. cereus 28-9, indicating that the genome of B. cereus 28-9 contained a single copy of $\operatorname{chiCW}$ (Fig. 2). 
Table 1. Purification of ChiCW from periplasmic fraction of E. coli DH5 $\alpha$ (pNTU55)

\begin{tabular}{cccccc}
\hline Purification step & $\begin{array}{c}\text { Total protein } \\
(\mathrm{mg})\end{array}$ & $\begin{array}{c}\text { Total activity } \\
\left(\mathrm{U}^{a}\right)\end{array}$ & $\begin{array}{c}\text { Specific activity } \\
(\mathrm{U} / \mathrm{mg})\end{array}$ & $\begin{array}{c}\text { Yield } \\
(\%)\end{array}$ & $\begin{array}{c}\text { Purification } \\
\text { fold }\end{array}$ \\
\hline Periplasmic fraction & 3.876 & 0.859 & 0.222 & 100.0 & 1.0 \\
Ammonium sulfate precipitation & 0.706 & 0.212 & 0.300 & 24.7 & 1.4 \\
Anion exchange chromatography & 0.158 & 0.144 & 0.911 & 16.8 & 4.1 \\
\hline
\end{tabular}

${ }^{a} 1 \mathrm{U}$ of activity $=1 \mu \mathrm{mol}$ of $4-\mathrm{MU}$ released per min.

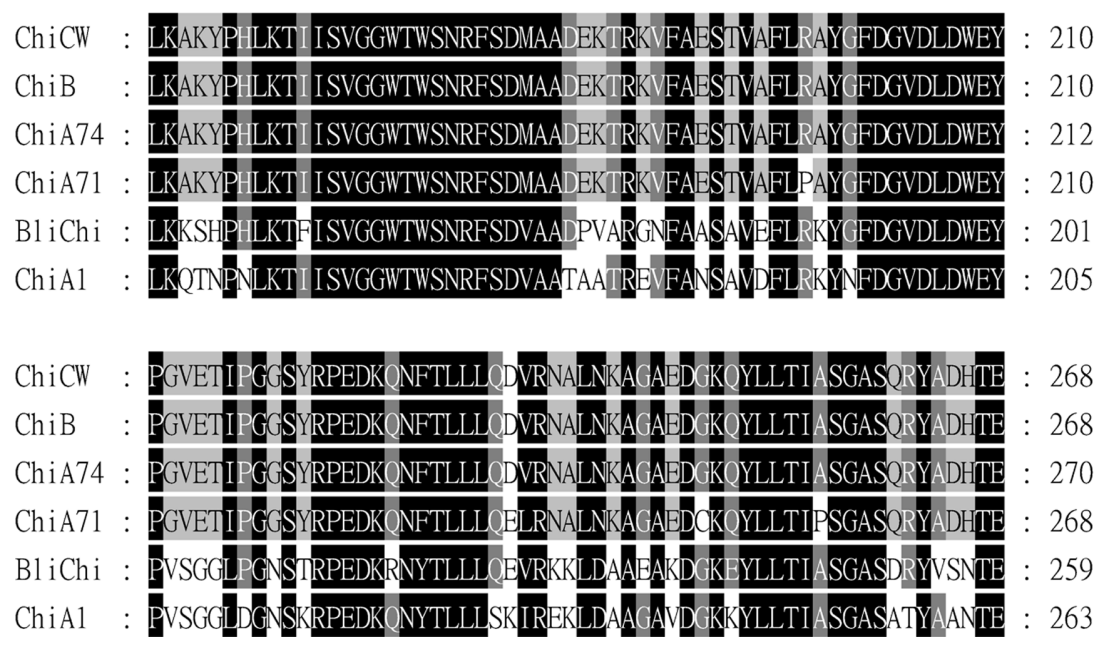

Fig. 4. Alignment of the peptide sequences of the catalytic domains of chitinases from different Bacillus spp. ChiCW (this study, accession number AF416570); ChiB, chitinase B of B. cereus CH (AB041932); ChiA74, chitinase A74 of B. thuringiensis serovar kenyae (AF424979); ChiA71, chitinase A71 of B. thuringiensis subsp. pakistani (AAB58579); BliChi, chitinase of B. licheniformis TP (U71214); ChiA1, chitinase A1 of $B$. circulans WL12 (M57601). The asterisks indicate the essential amino acid residues in the catalytic domains of chitinases.

\section{Expression and purification of ChiCW from recombinant} E. coli Chitinases secreted by B. cereus 28-9 appeared as three chitinolytic bands on the polyacrylamide gel as shown by in-gel activity assay. Two chitinolytic bands corresponded to $\mathrm{ChiCH}$ of $37 \mathrm{kDa}$ (Huang and Chen, 2004) and ChiCW of $70 \mathrm{kDa}$, respectively. A third chitinolytic band appeared at the position of $64 \mathrm{kDa}$. The recombinant plasmid pNTU55 harboring chiCW was constructed to express $\mathrm{ChiCW}$ in $E$. coli. ChiCW protein was purified from the periplasmic fraction of $E$. coli DH5 $\alpha$ (pNTU55) to near homogeneity as shown by SDS-PAGE analysis and in-gel activity assay. The molecular mass of ChiCW purified from $E$. coli was estimated to be $70 \mathrm{kDa}$, close to that secreted by B. cereus $28-9$ (Fig. 3). The degree of purification and yield at individual steps are given in Table 1.

Analysis and comparison of the amino acid sequence of ChiCW with other chitinases According to the conserved domain analysis using programs in NCBI, ChiCW precursor contained a signal peptide at $\mathrm{N}$ terminus, consisting of 31 amino acid residues characterized by the hydrophobic, positively charged region and a cleavage site for a specific signal peptidase between Leu-31 and Ala-32 was found (Perlman and Halvorson, 1983). The N-terminal signal peptide was followed by a catalytic domain of chitinase. Based on the homology of amino acid sequences, ChiCW was categorized in family 18 glycosyl hydrolase (Henrissat and Bairoch, 1993) and the sequence of the active site, FLRAYGFDGVDLDWEYPG from Phe-195 to Gly-212, was found (Fig. 4). Three essential conserved amino acid residues (Asp-205, Asp-207 and Glu-209) were found within the active site. These residues have also been found in ChiA1 of Bacillus circulans WL-12 (Watanabe et al., 1993) and ChiA of Serratia marcescens (Perrakis et al., 1994). Furthermore, Glu209 in ChiCW corresponded to Glu-315 of S. marcescens ChiA, which has been reported to be involved in chitinase catalysis (Perrakis et al., 1994). In addition, these three amino acid residues are fully conserved in chitinases from six Bacillus spp. (Fig. 4).

Fibronectin type-III like (FnIII) domain is in the middle region of $\mathrm{ChiCW}$ and has been reported to be present in several Bacillus chitinases. The amino acid sequence of the FnIII domain of ChiCW revealed a high homology to that of ChiB of B. cereus $\mathrm{CH}$, ChiA71 of B. thuringiensis subsp. pakistani and ChiA74 of B. thuringiensis serovar kenyae (Barboza-Corona et al., 2003; Mabuchi and Araki, 2001; Thamthiankul et al., 2001), but a lower homology to that of $B$. licheniformis TP and ChiA1 of B. circulans WL-12 


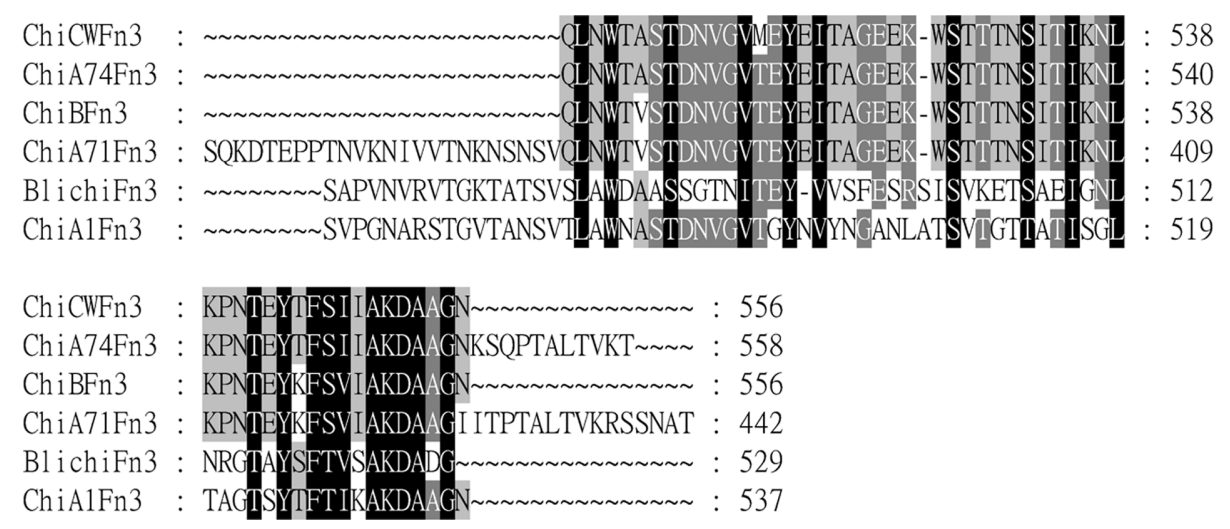

Fig. 5. Alignment of the peptide sequences of the Fibronectin type-III like domains of chitinases from different Bacillus spp.

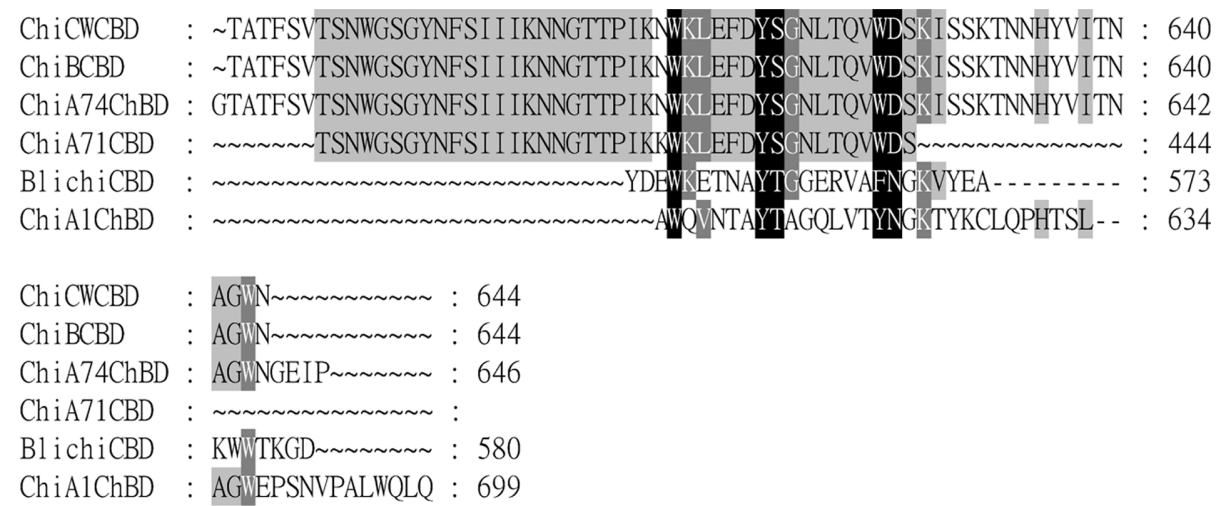

Fig. 6. Alignment of the peptide sequences of the chitin- and cellulose-binding domains of chitinases from different Bacillus spp. CBD and $\mathrm{ChBD}$ indicate the cellulose-binding domain and chitin-binding domain, respectively.

(Tantimavanich et al., 1998; Watanabe et al., 1990b). However, the conserved amino acid residues could be found in the FnIII domains of ChiCW and chitinases from five other Bacillus spp. (Fig. 5).

The C-terminal region of ChiCW was analyzed and specified to be a cellulose-binding domain (CBD). Alignment of the substrate binding domains of these Bacillus chitinases indicated that the residues Trp-610 and Tyr-616 of ChiCW were highly conserved among the domains involved in the binding of chitin and/or cellulose substrates (Barboza-Corona et al., 2003; Mabuchi and Araki, 2001; Tantimavanich et al., 1998; Thamthiankul et al., 2001; Watanabe et al., 1994) (Fig. 6).

Inhibition by ChiCW on conidial germination of $B$. elliptica The effect of ChiCW to inhibit conidial germination of $B$. elliptica B061 was demonstrated by an in vitro assay using the $\mathrm{ChiCW}$ protein purified from $E$. coli harboring chicW. An $84 \%$ inhibition on conidial germination of $B$. elliptica B061 was exhibited by the purified ChiCW protein at a dose of $28 \mu \mathrm{U}$. The inhibition rate could still be maintained at $20 \%$ at a dose of $3.5 \mu \mathrm{U}$ (Table 2). The conidia of $B$. elliptica B061 incubated with ChiCW frequently became enlarged and the elongation of germination tubes was generally retarded, as observed under a light microscope (Fig. 7).

\section{Discussion}

Lily leaf blight caused by the fungal pathogen, B. elliptica, is the most severe and destructive disease of the field-grown lilies. It is difficult to control $B$. elliptica by fungicides because this fungus develops resistance to fungicides frequently (Chastagner and Riley, 1990; Migheli et al., 1990).

Table 2. Effect of $\mathrm{ChiCW}$ on conidial germination of $B$. elliptica ${ }^{a}$

\begin{tabular}{cc}
\hline ChiCW activity $(\mu \mathrm{U})$ & $\begin{array}{c}\text { Inhibition rate of conidial } \\
\text { germination }(\%)\end{array}$ \\
\hline 28.0 & $84 \pm 1$ \\
14.0 & $78 \pm 3$ \\
7.0 & $29 \pm 8$ \\
3.5 & $20 \pm 2$ \\
$0.0^{b}$ & 0 \\
\hline${ }^{a}$ Each treatment included $4 \mu 1$ of purified ChiCW from E. coli \\
DH5 $\alpha$ (pNTU55) and $4 \mu$ l of conidial suspension of B. elliptica \\
B061 (10 conidia/ml). The mixture was placed on slides in a \\
moist petri dish for $12 \mathrm{~h}$ before microscopic examination. \\
${ }^{b}$ Potassium phosphate buffer (100 mM, pH 6.0) was used as a \\
negative control.
\end{tabular}


(A)

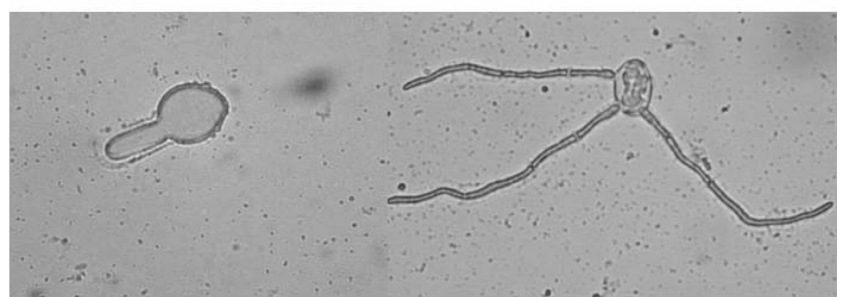

Fig. 7. Effect of $\mathrm{ChiCW}$ on conidial germination of B. elliptica. Conidia were treated with purified $\mathrm{ChiCW}$ from $E$. coli DH5 $\alpha$ (pNTU55) (A) or $100 \mathrm{mM}$ potassium phosphate buffer, $\mathrm{pH}$ 6.0 (B). The conidium treated with $\mathrm{ChiCW}$ became enlarged and did not fully germinate.

Therefore, selection of antagonistic microorganisms to perform biological control is considered an alternative practice. In the study of Chiou and Wu (2001), several antagonistic bacteria were selected and examined for their biocontrol activities. In this study, chitinolytic B. cereus 28-9 was selected and its potential biocontrol activity was demonstrated by a detached leaf assay and dual culture assay. According to the studies of Chiou and $\mathrm{Wu}$ (2001) and Gould et al. (1996), using detached plant tissues for bioassay is a simple, effective and time-saving method. The behavior of antagonists on the detached leaves is positively correlated to that on the whole plants (Chiou and Wu, 2001). Since $B$. cereus $28-9$ could inhibit the infection by $B$. elliptica B061 on detached lily leaves and exhibit antifungal activity as demonstrated by dual culture assay, we proposed that $B$. cereus 28-9 could be a biocontrol agent to protect field-grown lilies from $B$. elliptica infection.

In addition, $\mathrm{ChiCW}$ purified from the periplasmic fraction of $E$. coli DH5 $\alpha$ (pNTU55) effectively inhibited conidial germination of $B$. elliptica B061; thus ChiCW contributing to the antagonistic activity of $B$. cereus $28-9$ against $B$. elliptica was presumed. Other factors such as induced plant resistance, antifungal metabolites or a competitive colonization on the leaf surface might also be involved in the antagonism of $B$. cereus 28-9 against $B$. elliptica.

In the zymogram analysis, three chitinases appeared to be secreted by B. cereus 28-9. Besides ChiCW (70 kDa) and ChiCH $(37 \mathrm{kDa})$, a third chitinolytic band was observed at position of $64 \mathrm{kDa}$ and was presumed to be a proteolytic modification product of ChiCW. Similar phenomenon of proteolytic modification of chitinases has also been reported in other bacteria (Mabuchi et al., 2000; Tantimavanich et al., 1998; Thamthiankul et al., 2001; Watanabe et al., 1990a).

Acknowledgment This study was supported by the National Science Council, Taiwan, Republic of China.

\section{References}

Barboza-Corona, J. E., Nieto-Mazzocco, E., Velázquez-Robledo,
R., Salcedo-Hernandez, R., Bautista, M., Jiménez, B. and Ibarra, J. E. (2003) Cloning, sequencing, and expression of the chitinase gene chiA74 from Bacillus thuringiensis. Appl. Environ. Microbiol. 69, 1023-1029.

Bartnicki-Garcia, S. (1969) Cell wall chemistry, morphogenesis, and taxonomy of fungi. Annu. Rev. Microbiol. 22, 87-108.

Bradford, M. M. (1976) A rapid and sensitive method for the quantitation of microgram quantities of protein utilizing the principle of protein-dye binding. Anal. Biochem. 72, 248-254.

Brunel, B., Périssol, C., Fernandez, M., Boeufgras, J. M. and Le Petit, J. (1994) Occurrence of Bacillus species on evergreen oak leaves. FEMS Microbiol. Ecol. 14, 331-342.

Chastagner, G. A. and Riley, K. (1990) Occurrence and control of benzimidazole and dicarboximide resistant Botrytis spp. on bulb crops in Western Washington and Oregon. Acta Hort. 266, 437-445.

Chernin, L., Ismailov, Z., Haran, S. and Chet, I. (1995) Chitinolytic Enterobacter agglomerans antagonistic to fungal plant pathogens. Appl. Environ. Microbiol. 61, 1720-1726.

Chiou, A. L. and Wu, W. S. (2001) Isolation, identification and evaluation of bacterial antagonists against Botrytis elliptica on lily. J. Phytopathol. 149, 319-324.

Cohen-Kupiec, R. and Chet, I. (1998) The molecular biology of chitin digestion. Curr. Opin. Biotechnol. 9, 270-277.

Doss, R. P., Chastagner, G. A. and Riley, K. L. (1984) Techniques for inoculum production and inoculation of lily leaves with Botrytis elliptica. Plant Dis. 68, 854-856.

Elad, Y. (1996) Mechanisms involved in the biological control of Botrytis cinerea incited diseases. Eur. J. Plant Pathol. 102, 719732.

Emmert, E. A. B. and Handelsman, J. (1999) Biocontrol of plant disease: a (Gram-) positive perspective. FEMS Microbiol. Lett. 171, 1-9.

Felse, P. A. and Panda, T. (1999) Regulation and cloning of microbial chitinase genes. Appl. Microbiol. Biotechnol. 51, 141151.

Flach, J., Pilet, P. E. and Jollès, P. (1992) What's new in chitinase research? Experientia 48, 701-716.

Freeman, S., Minzm O., Kolesnik, I., Barbul, O., Zveibil, A., Maymon, M., Nitzani, Y., Kirshner, B., Rav-David, D., Bilu, A., Dag, A., Shafir, S. and Elad, Y. (2004) Trichoderma biocontrol of Colletotrichum acutatum and Botrytis cinerea and survival in strawberry. Eur. J. Plant Pathol. 110, 361-370.

Gooday, G.. W. (1990) The ecology of chitin degradation; in Advances in Microbial Ecology, Marshall, K. C. (ed.), pp. 387430, Plenum Press, New York, USA.

Gould, A. B., Kobayashi, D. Y. and Bergen, M. S. (1996) Identification of bacteria for biological control of Botrytis cinerea on petunia using a petal disk assay. Plant Dis. 80, 1029-1033.

Graham, L. S. and Sticklen, M. B. (1994) Plant chitinases. Can. J. Bot. 72, 1057-1083.

Henrissat, B. and Bairoch A. (1993) New families in the classification of glycosyl hydrolases based on amino acid sequence similarities. Biochem. J. 293, 781-788.

Hsieh, T. F. and Huang, J. W. (1998) Factors affecting disease development of Botrytis leaf blight of lily caused by Botrytis elliptica. Plant Pathol. Bull. 40, 227-240.

Huang, C. J. and Chen, C. Y. (2004) Gene cloning and biochemical characterization of chitinase $\mathrm{CH}$ from Bacillus 
cereus 28-9. Ann. Microbiol. 54, 289-297.

Keim, P., Kalif, A., Schupp, J., Hill, K., Travis, S. E., Richmond, K., Adair, D. M., Hugh-Jones, M., Kuske, C. R. and Jackson, P. (1997) Molecular evolution and diversity in Bacillus anthracis as detected by amplified fragment length polymorphism markers. J. Bacteriol. 179, 818-824.

Kobayashi, D. Y., Reedy, R. M., Bick, J. A. and Oudemans, P. V. (2002) Characterization of a chitinase gene from Stenotrophomonas maltophilia strain $34 \mathrm{~S} 1$ and its involvement in biological control. Appl. Environ. Microbiol. 68, 1047-1054.

Laemmli, U. K. (1970) Cleavage of structural proteins during the assembly of the head of bacteriophage T4. Nature 227, 680685.

Mabuchi, N. and Araki, Y. (2001) Cloning and sequencing of two genes encoding chitinases A and B from Bacillus cereus $\mathrm{CH}$. Can. J. Microbiol. 47, 895-902.

Mabuchi, N., Hashizume, I. and Araki, Y. (2000) Characterization of chitinases excreted by Bacillus cereus CH. Can. J. Microbiol. 46, 370-375.

Manoil, C. and Beckwith, J. (1986) A genetic approach to analyzing membrane protein topology. Science 233, 1403-1408.

Martinez, C., Michaud, M., Belanger, R. R. and Tweddell, R. J. (2002) Identification of soils suppressive against Helminthosporium solani, the causal agent of potato silver scurf. Soil Biol. Biochem. 34, 1861-1868.

Migheli, Q., Aloi, C. and Gullino, M. L. (1990) Resistance of Botrytis elliptica to fungicides. Acta Hort. 266, 429-436.

Perlman, D. and Halvorson, H. O. (1983) A putative signal peptidase recognition site and sequence in eukaryotic and prokaryotic signal peptides. J. Mol. Biol. 167, 391-409.

Perrakis, A., Tews, I., Dauter, Z., Oppenheim, A. B., Chet, I., Wilson, K. S. and Vorgias, C. E. (1994) Crystal structure of a bacterial chitinase at $2.3 \AA$ resolution. Structure 2, 1169-1180.

Pleban, S., Chernin, L. and Chet, I. (1997) Chitinolytic activity of an endophytic strain of Bacillus cereus. Lett. Appl. Microbiol. 25, 284-288.
Sietsma, J. H. and Wessels, J. G. H. (1979) Evidence for covalent linkages between chitin and $\beta$-glucan in a fungal wall. J. Gen. Microbiol. 114, 99-108.

Silo-Suh, L. A., Lethbridge, B. J., Raffel, S. J., He, H., Clardy, J. and Handelsman, J. (1994) Biological activities of two fungistatic antibiotics produced by Bacillus cereus UW85. Appl. Environ. Microbiol. 60, 2023-2030.

Tantimavanich, S., Pantuwatana, S., Bhumiratana, A. and Panbangred, W. (1998) Multiple chitinase enzymes from a single gene of Bacillus licheniformis TP-1. J. Ferment. Bioeng. 85, 259-265.

Thamthiankul, S., Suan-Ngay, S., Tantimavanich, S. and Panbangred, W. (2001) Chitinase from Bacillus thuringiensis subsp. pakistani. Appl. Microbiol. Biotechnol. 56, 395-401.

Trudel, J. and Asselin, A. (1989) Detection of chitinase activity after polyacrylamide gel electrophoresis. Anal. Biochem. 178, 362-366.

Watanabe, T., Ito, Y., Yamada, T., Hashimoto, M., Sekine, S. and Tanaka, H. (1994) The roles of the C-terminal domain and type III domains of chitinase A1 from Bacillus circulans WL-12 in chitin degradation. J. Bacteriol. 176, 4465-4472.

Watanabe, T., Kobori, K., Miyashita, K., Fujii, T., Sakai, H., Uchida, M. and Tanaka, H. (1993) Identification of glutamic acid 204 and aspartic acid 200 in chitinase A1 of Bacillus circulans WL-12 as essential residues for chitinase activity. $J$. Biol. Chem. 268, 18567-18572.

Watanabe, T., Oyanagi, W., Suzuki, K. and Tanaka, H. (1990a) Chitinase system of Bacillus circulans WL-12 and importance of chitinase A1 in chitin degradation. J. Bacteriol. 172, 40174022 .

Watanabe, T., Suzuki, K., Oyanagi, W., Ohnishi, K. and Tanaka, H. (1990b) Gene cloning of chitinase A1 from Bacillus circulans WL-12 revealed its evolutionary relationship to Serratia chitinase and to the type III homology units of fibronectin. J. Biol. Chem. 265, 15659-15665. 